\title{
Genetic Diversity and Ecogeographical Phylogenetic Relationships among Peach and Nectarine Cultivars Based on Simple Sequence Repeat (SSR) Markers
}

\author{
Jaeho Yoon \\ Institute of Botany, Chinese Academy of Sciences, 100093 Beijing, P.R. China; College of Agronomy \\ and Biotechnology, China Agricultural University, 100094 Beijing, P.R. China \\ Dongcheng Liu \\ Institute of Genetic and Developmental Biology, Chinese Academy of Sciences, 100101 Beijing, P.R. \\ China
}

\author{
Wonseob Song \\ Division of Plant Science, Sunchon National University, Sunchon 540-742, Korea \\ Weisheng Liu \\ Liaoning Institute of Pomology, Yingkou, 115009 Liaoning, P.R. China \\ Aimin Zhang1 \\ Institute of Genetic and Developmental Biology, Chinese Academy of Sciences, 100101 Beijing, P.R. \\ China \\ Shaohua Li'
Institute of Botany, Chinese Academy of Sciences, 100093 Beijing, P.R. China
}

\begin{abstract}
Additional Index words. Prunus persica, Chinese local cultivar, botanical variety, polymorphism, Nei's genetic distances, evolutionary relationship

ABStRaCt. The genetic relationships among 96 peach and nectarine [Prunus persica $($ L.) Batsch.] genotypes and botanical varieties originating from different ecogeographical regions of China, Japan, North America, and South Korea were evaluated with 33 SSR markers screened from 108 published SSR markers developed for peach or sweet cherry (P. avium L.). The 33 SSRs detected polymorphisms among 96 genotypes and revealed a total of 283 alleles with an average of 8.6 alleles per locus. The polymorphism information content (PIC) value ranged from 0.40 (BPPCT041) to 0.98 (BPPCT009) with an average of 0.80 . Unweighted pair group method average (UPGMA) cluster analysis based on Nei's genetic distances classified genotypes into six groups, corresponding to their ecogeographical origin. Group I consisted of northern Chinese and northwestern Chinese local cultivars, and was divided into two subgroups, white and yellow peaches. Group II contained mainly southern Chinese local, Japanese, and North American cultivars and can be divided into four subgroups: Japanese white, Chinese flat, North American yellow, and some Chinese local ornamental peach cultivars. Groups III, IV, and V were comprised of Chinese local ancient cultivars, and contained 'Xinjiangdatianren' and 'Renmiantao', Chinese dwarf cultivars, and 'Fenshouxing', respectively. Group VI had only 'Baishanbitao', a Chinese ornamental cultivar. Northern and northwestern Chinese local cultivars clustered together with a greater diversity than southern Chinese local cultivars, indicating that the northern and northwestern Chinese local cultivars are similar ecotypes, and southern Chinese local cultivars are a subset of the northern Chinese group. Moreover, the Japanese and North American genotypes had a close phylogenetic relationship with southern Chinese local cultivars. The taxonomic placement of P.ferganensis (Kost. et Kiab) Kov. et Kost. and the phylogenetic relationship of 'Baishanbitao' with peaches are discussed.
\end{abstract}

Peaches and nectarines are known to be native to China. Peaches were cultivated there for at least 3000 years, and nectarines over 2000 years, in the northern plain of China, and then spread to southern China, especially along the Yangtze River Valley (Wang and Zhuang, 2001). With a long history of cultivation and extensive geographical distribution, two different ecological types, northern Chinese and southern Chinese, and four botanical varieties, $P$.

Received for publication 13 Sept. 2005. Accepted for publication 31 Mar. 2006. This research was funded by the programme of Chinese Academy of Sciences. Institute of Botany and China Agricultural University have contributing equally to this work. We thank Professor Douglas. D. Archbold, University of Kentucky, for his critical review of the manuscript.

'Corresponding authors: e-mail: shhli@ibcas.ac.cn; amzhang@genetics.ac.cn persica var. nectarina (Ait.) Maxim., P. persica var. compressa (Loud.) Bean, P. persica var. densa Makino, and P. persica var. duplex Rehd., have been described for peaches (Li et al., 1997), and numerous local cultivars can now be found in China (Wang and Zhuang, 2001). Moreover, there are numerous germplasm resources of peaches and nectarines in the world due to their introduction into other countries as early as the Han Dynasty, about 200 BCE, into Persia along the Silk Road, distribution to the European countries of the Mediterranean thereafter, and introduction into North America in the 16th century and into Japan in the 18th century (Wang and Zhuang, 2001).

Peach and nectarine cultivars typically have a narrow genetic base due to the limited number of genotypes used as parents in 
breeding programs. Consequently, the commercial cultivars of peaches and nectarines used throughout the world have a restricted range of adaptability as compared to the native germplasm extant in China.

The analysis of genetic relationships among germplasm resources can supply basic information for broadening the genetic base of breeding germplasm. Among various methods of characterization, those methods based on morphological, palynological, cytological, and phytochemical traits have the disadvantages of an environmental effect and a low degree of polymorphism, while DNA-based markers can overcome such problems. Molecular markers such as RFLPs (Belthoff et al., 1993; Rajapakse et al., 1995), RAPDs (Chaparro et al., 1994; Rajapakse et al., 1995), and AFLPs (Aranzana et al., 2003a) have been used during the last 10 years for the estimation of genetic relationships and in genetic linkage mapping of the peach genome. SSR markers are useful in genomic research due to the high polymorphism and even distribution through the genome (Yamamoto et al., 2002). Saturation genomic maps based on SSR markers are available for human (Dib et al., 1996) and mouse (Dietrich et al., 1996) genomes.

The genetic relationships among peach and nectarine cultivars have been previously reported (Martinez-Gomez et al., 2003; Yamamoto et al., 2003). However, the research was carried out only on peach and nectarine cultivars originating from the U.S. and Europe (Dirlewanger et al., 2002; Sosinski et al., 2000; Testolin et al., 2000; Wang et al., 2002) and did not include germplasm from Asia. Studies of 212 peach and nectarine cultivars with 16 previously developed SSRs allowed classification into $\mathrm{mf}$ and nmf types (Aranzana et al., 2003b). Analysis of a larger group of cultivars with more diverse origins would allow ecogeographical relationships to be investigated.

The objectives of the present study were to evaluate the diversity and phylogenetic relationships of peach germplasm, specifically focusing on the phylogenetic relationships among the different geographical cultivars or botanical varieties in China, and to investigate phylogenetic relationships between the ecogeographical types originating from China, Japan, Korea, and North America.

\section{Materials and Methods}

Plant Materials. Ninety-six peach and nectarine cultivars from China and foreign sources were used in this study (Table 1). The materials include 28 local and eight improved peach and nectarine cultivars, representing flat $[P$. persica var. compressa $(\mathrm{n}=9)]$, dwarf $[P$. persica var. densa $(\mathrm{n}=7)]$, and ornamental $[P$. persica var. duplex $(\mathrm{n}=8)]$ cultivars, and one kindred species (P. ferganensis) from China. In addition, 20 Japanese, 21 North American, and three South Korean cultivars were studied. All cultivars were donated by the National Germplasm Repository for Peaches and Nectarines in the Institute of Forestry and Fruit

Table 1. Characteristics of peach and nectarine cultivars used for genetic diversity analysis, with ecological type, parental relations, origin country, and fruit type.

\begin{tabular}{|c|c|c|c|c|c|c|}
\hline Group & Accession no. & Cultivar & Parental relations $^{\mathrm{z}}$ & Source $^{y}$ & Origin & Type $^{x}$ \\
\hline \multicolumn{7}{|l|}{ Chinese local: } \\
\hline \multirow[t]{10}{*}{ Southern ecological type } & 1 & Baimangpantao & Unknown & A & Shanghai & FWMC \\
\hline & 2 & Changshengpantao & Unknown & A & Shanghai & FWNC \\
\hline & 3 & Chenpupantao & Unknown & A & Shanghai & FWMC \\
\hline & 4 & Chongbanyulu & Unknown & B & Zhejiang & CWMC \\
\hline & 5 & Huangjintao & Unknown & B & Zhejiang & CYNC \\
\hline & 6 & Sahuahongpantao & Unknown & A & Shanghai & FWMC \\
\hline & 7 & Shilinhuangrou & Unknown & A & Yunnan & CYMC \\
\hline & 8 & Xinbaitao & Unknown & B & Zhejiang & CWNS \\
\hline & 9 & Yulupantao & Unknown & A & Zhejiang & FWMC \\
\hline & 10 & Yunshu 1\# & Shanghaishuimi $\mathrm{x}$ Xiaoshu & A & Zhejiang & CWMC \\
\hline \multicolumn{7}{|l|}{ Chinese local: } \\
\hline \multirow[t]{9}{*}{ Northern ecological type } & 11 & Diaozhibai & Unknown & A & Hebei & CWNF \\
\hline & 12 & Feichenghonglitao & Unknown & A & Shandong & CWMC \\
\hline & 13 & Shenzhoubaimi & Unknown & A & Hebei & CWMC \\
\hline & 14 & Wuyuexian & Unknown & A & Hebei & CWNF \\
\hline & 15 & Wuyuexianbiangan & Unknown & A & Beijing & FWNC \\
\hline & 16 & Xiangtao & Unknown & A & Huabei & CWMC \\
\hline & 17 & Xiangjiaotao & Unknown & A & Liaoning & CWNC \\
\hline & 18 & Yixianbai & Unknown & A & Huabei & CWNS \\
\hline & 19 & Zaohuangjin & Unknown & A & Beijing & CYNC \\
\hline \multicolumn{7}{|l|}{ Chinese local: } \\
\hline \multirow[t]{9}{*}{ Northwestern ecological type } & 20 & Linbai $4 \#$ & Unknown & A & Gansu & CWNC \\
\hline & 21 & Linbai 7\# & Unknown & A & Gansu & CWNC \\
\hline & 22 & Linhuang 9\# & Unknown & A & Gansu & CYNC \\
\hline & 23 & Long 1-2-4\# & Unknown & A & Gansu & CYNC \\
\hline & 24 & Long 2-4-6\# & Unknown & A & Gansu & CYNC \\
\hline & 25 & Roupantao & Unknown & A & Gansu & FWNC \\
\hline & 26 & Xizhuang 1\# & Unknown & A & Gansu & CYNC \\
\hline & 27 & Zhangbai 8\# & Unknown & A & Gansu & CWNC \\
\hline & 28 & Zhanghuang 7\# & Unknown & A & Gansu & CYNC \\
\hline
\end{tabular}

Table 1 continued on next page. 
Research of the Beijing Academy of Agricultural Sciences, Zhengzhou Fruit Tree Research Institute of the China Academy of Agricultural Sciences, and the Fruit Station of Sunchon National University in South Korea. Leaf tissues were preserved at -80 ${ }^{\circ} \mathrm{C}$ before DNA extraction.

DNA extraction. Genomic DNA was extracted from newly emerged young leaves according to the $2 \%$ cetyltrimethylammonium bromide (CTAB) method described by Doyle and Doyle (1990) with minor modifications. Briefly, approximately $0.1 \mathrm{~g}$ frozen leaves were placed in a $1.5 \mathrm{~mL}$ Eppendorf tube and ground to a fine powder in liquid nitrogen with a pestle. The powder was added to $650 \mu \mathrm{L}$ of extraction buffer [2\% (w/v) CTAB, 1.4 м NaCl, 100 mмTris-HCl, 20 mм EDTA pH 8.0, 2\% $\beta$-mercaptoethanol, and $1 \%(\mathrm{w} / \mathrm{v})$ polyvinylpyrrolidone] and incubated at $65{ }^{\circ} \mathrm{C}$ for 30 to $60 \mathrm{~min}$. After placing in an icebath for $5 \mathrm{~min}$, the mixture was extracted once with 1 volume chloroform : isoamyl alcohol [24:1 (v/v)] by gently homogenizing, and was centrifuged at $15,294 g_{\mathrm{n}}$ at $4{ }^{\circ} \mathrm{C}$ for $15 \mathrm{~min}$. The upper aqueous phase was transferred to a new tube for RNAase treatment with $2 \mu \mathrm{L} 10 \mathrm{mg} \cdot \mathrm{mL}^{-1} \mathrm{RNAase}$ and incubated at $37^{\circ} \mathrm{C}$ for 30 to 60 min. After being extracted with 1 volume of choroform : isoamyl alcohol as above, the top aqueous phase was precipitated with two volumes of cold absolute ethanol. The DNA pellet was washed three times with $70 \%(\mathrm{v} / \mathrm{v})$ ethanol and dissolved in 100 $\mu \mathrm{L}$ sterile water after the ethanol had evaporated completely. The quality of DNA was checked on a $1 \%(\mathrm{w} / \mathrm{v})$ agarose gel and its concentration determined by an Eppendorf Biophotometer (Eppendorf AG, Hamburg, Germany) at $260 \mathrm{~nm}$. A portion of

Table 1. Continued from previous page.

\begin{tabular}{|c|c|c|c|c|c|c|}
\hline Group & Accession no. & Cultivar & Parental relations ${ }^{\mathrm{z}}$ & Source $^{y}$ & Origin & Type $^{x}$ \\
\hline \multirow[t]{8}{*}{ Chinese improved } & 29 & Chunlei & Sunagowase $\mathrm{x}$ Baixianglu & A & China & CWMS \\
\hline & 30 & Hongganlu & Hongtiantao natural crossing & A & China & CWNC \\
\hline & 31 & Qingfeng & Okubo x Amsden June & A & China & CWMS \\
\hline & 32 & Shuguang & LeGrant $x$ Ruiguang 2\# & B & China & NYMC \\
\hline & 33 & Xiaohua'aibaotai & Elberta mutation & B & China & CYMF \\
\hline & 34 & Zaokuimi & Wanshudapantao x Yangzhou 124 pantao & $\mathrm{O} \quad \mathrm{A}$ & China & FWMC \\
\hline & 35 & Zaoshuomi & Baimangpantao $\times$ Zhaoxia & A & China & FWMC \\
\hline & 36 & Zaoyan & Unknown & A & China & CWMC \\
\hline \multirow[t]{8}{*}{ Chinese ornamental } & 37 & Baishanbitao & Unknown & B & China & \\
\hline & 38 & Hongchuizhi & Unknown & B & China & \\
\hline & 39 & Honghuabitao & Unknown & B & Beijing & \\
\hline & 40 & Hongyetao & Unknown & B & China & \\
\hline & 41 & Jiangtao & Unknown & B & China & \\
\hline & 42 & Mantianhong & Hakuho $x$ Shouxingtao & B & China & CWMC \\
\hline & 43 & Renmiantao & Unknown & B & China & \\
\hline & 44 & Zhufenchuizhi & Unknown & $\mathrm{B}$ & China & \\
\hline \multirow[t]{7}{*}{ Chinese dwarf } & 45 & Fenshouxing & Unknown & B & China & CWMF \\
\hline & 46 & S1 & Hakuho $\mathrm{x}$ Shouxingtao & B & China & CWMC \\
\hline & 47 & S2 & Hakuho $\mathrm{x}$ Shouxingtao & B & China & CWMC \\
\hline & 48 & S9 & Hakuho $x$ Shouxingtao & B & China & CWMC \\
\hline & 49 & Shoubai & Unknown & B & China & CWNF \\
\hline & 50 & Shoufen & Unknown & B & China & CWNF \\
\hline & 51 & Shouxingtao & Unknown & A & Yangtze River & CWMF \\
\hline \multirow[t]{20}{*}{ Japanese cultivars } & 52 & Denjiuro & Unknown & B & Japan & CWNF \\
\hline & 53 & Hakuho & Hakuto $\mathrm{x}$ Tasubanawase & A & Japan & CWNC \\
\hline & 54 & Higawahakuho & Hakuho mutation & $\mathrm{C}$ & Japan & CWNC \\
\hline & 55 & Itsumihakuto & Gawanagatohak x Yamanehakuto & $\mathrm{C}$ & Japan & CWNC \\
\hline & 56 & Itsumiyasuimitsu & Asamahakuto mutation & $\mathrm{C}$ & Japan & CWMC \\
\hline & 57 & Kanouganghakuto & Asamahakuto mutation & $\mathrm{C}$ & Japan & CWNS \\
\hline & 58 & Kansukehakuto & Aiwahakuto mutation & $\mathrm{C}$ & Japan & CWMC \\
\hline & 59 & Marumihakuto & Unknown & $\mathrm{C}$ & Japan & CWNC \\
\hline & 60 & Matsumori & Hakuho mutation & A & Japan & CWNC \\
\hline & 61 & Maysummer & Unknown & $\mathrm{C}$ & Japan & CWNC \\
\hline & 62 & Meisei & Yamashita x Sims & A & Japan & CYNC \\
\hline & 63 & Nagasawahakuho & Hakuho mutation & $\mathrm{C}$ & Japan & CWNC \\
\hline & 64 & Nishio Gold & Goldenpeach mutation & $\mathrm{C}$ & Japan & CYNC \\
\hline & 65 & Okubo & Hakuto mutation & A & Japan & CWMC \\
\hline & 66 & Ryuouhakuto & Unknown & $\mathrm{C}$ & Japan & CWNC \\
\hline & 67 & Sikahakuto & Unknown & A & Japan & CWMC \\
\hline & 68 & Sunagowase & Okubomutation & A & Japan & CWNS \\
\hline & 69 & Takeihakuho & Hakuho mutation & $\mathrm{C}$ & Japan & CWNS \\
\hline & 70 & Tasubanawase & Denjiuro mutation & B & Japan & CWMS \\
\hline & 71 & Youhou & Unknown & $\mathrm{C}$ & Japan & CWMS \\
\hline
\end{tabular}

Table 1 continued on next page. 
the DNA was diluted to $20 \mathrm{ng} \cdot \mu \mathrm{L}^{-1}$ with double distilled water for SSR analysis. Stock and diluted DNA samples were stored at -20 and $4{ }^{\circ} \mathrm{C}$, respectively.

PCR-AMPlifiCATION AND PRODUCT ELECTROPHORESIS. Of 33 SSR primers, 32 were previously developed in peach and one in sweet cherry, which were screened from 108 SSR markers reported by Cipriani et al. (1999), Sosinski et al. (2000), Downey and Iezzoni (2000), Aranzana et al. (2002), and Dirlewanger et al. (2002), and were used to analyze the genetic relationships among the 96 peach and nectarine cultivars (Table 2).

PCR amplifications were conducted in a total volume of $20 \mu \mathrm{L}$ with $20 \mathrm{ng}$ template DNA, $0.2 \mu \mathrm{M}$ of forward and reverse primers, $200 \mu \mathrm{M}$ each of dNTP, and $1 \mathrm{U}$ of Taq polymerase in $1 \times$ PCR buffer [10 mm Tris- $\mathrm{HCl}$, pH 9.0, $10 \mathrm{~mm} \mathrm{KCl,} 8 \mathrm{~mm}\left(\mathrm{NH}_{4}\right)_{2} \mathrm{SO}_{4}$, $1.5 \mathrm{~mm} \mathrm{Mg}^{2+}$, and $\left.0.05 \% \mathrm{NP}-40\right]$. The amplification process was programmed in a PE9700 Thermal Cycler (PerkinElmer, Wellesley, Mass.) under the following conditions: $5 \mathrm{~min}$ at 95 ${ }^{\circ} \mathrm{C}, 35$ cycles of $45 \mathrm{~s}$ at $94{ }^{\circ} \mathrm{C}, 45 \mathrm{~s}$ at an appropriate annealing temperature $\left(50\right.$ to $\left.60^{\circ} \mathrm{C}\right), 45 \mathrm{~s}$ at $72^{\circ} \mathrm{C}$, and finishing with $8 \mathrm{~min}$ at $72{ }^{\circ} \mathrm{C}$. PCR products were electrophoresed using a sequencing cell (Bio-Rad Laboratories, Hercules, Calif.) with $4 \%$ denatured polyacrylamide gel at $75 \mathrm{~W}$ power in $0.2 \times \mathrm{TBE}$ buffer, and the gel was silver stained on the glass plates.

Data Analysis. The genetic distance between cultivars was estimated with Nei's parameter (Nei, 1972), implemented by the SimQual procedure of the NTSYSpc version 2.1 program (Rohlf, 1994). The presence (1) or absence (0) of amplified fragments was recorded for each cultivar, and a similarity matrix was generated using the equation discussed in Nei (1972), based on the proportion of shared amplification fragments. A dendrogram was constructed from the data matrix by clustering UPGMA with SAHN-clustering. The values of polymorphic information content (PIC) were calculated for each marker (Anderson et al., 1993).

\section{Results}

Polymorphism of SSR markers. Very high levels of polymorphisms were detected among the 96 peach and nectarine cultivars from the present study (Table 2). A total of 283 alleles were revealed by 33 SSRs selected from the published 108 SSR markers by clearness and specificity with an average of 8.6 alleles per locus. Thirteen SSR markers had more than 10 alleles each, of which marker CPPCT031 contained 16 alleles, the largest number found among the 33 markers, while marker BPPCT005 was the least polymorphic with only two alleles. The PIC value ranged from 0.40 (BPPCT041) to 0.98 (BPPCT009) with an average of 0.80 .

Classification of Peach group by genetic distance. The genetic distances among 96 peaches and nectarines were calculated based on 283 bands amplified by 33 SSR markers. In terms of the genetic distance among cultivars, the closest was between 'Sikahakuho' and 'Matsumori' (0.036), the farthest between 'Denjiuro' and 'Baishanbitao' (6.860), and the average genetic distance among the total 4560 combinations was 1.265 .

Table 1. Continued from previous page.

\begin{tabular}{|c|c|c|c|c|c|c|}
\hline Group & Accession no. & Cultivar & Parental relations $^{\mathrm{z}}$ & Sourcey & Origin & Typex \\
\hline \multirow[t]{21}{*}{ North American cultivars } & 72 & Babygold 5 (NJC3) & PI35201 x NJ196 & A & U.S. & CYNC \\
\hline & 73 & Babygold 6 & NJ13232 x NJ196 & A & U.S. & CYNC \\
\hline & 74 & Babygold 7 & $($ Lemon Free x PI35201) x NJ196 & A & U.S. & CYNC \\
\hline & 75 & Babygold 8 & PI35201 x Ambergem & B & U.S. & CYNC \\
\hline & 76 & Bailey & Unknown & A & U.S. & CWMF \\
\hline & 77 & Dixon & Orange cling $\times$ Australian Muir & A & U.S. & CYNC \\
\hline & 78 & Frederic & NJC95 x D42-13W & A & U.S. & CYNC \\
\hline & 79 & Flordacrest & Fla.5-13N x Flordaking & $\mathrm{B}$ & U.S. & CYMS \\
\hline & 80 & Flordaking & Fla.9-67 x Early Amber & B & U.S. & CYMC \\
\hline & 81 & Harbrite & Redskin $\times$ Sunhaven & $\mathrm{B}$ & Canada & CYMS \\
\hline & 82 & Harcrest & Redskin x H4219 & $\mathrm{B}$ & Canada & CYMF \\
\hline & 83 & Harvester & Redskin $\times$ Southernglow & $\mathrm{B}$ & U.S. & CYMF \\
\hline & 84 & Havis & Dixiland x Sentinel & A & U.S. & CYMF \\
\hline & 85 & NJC96 & Unknown & A & U.S. & CYNC \\
\hline & 86 & NJC108 & Unknown & $\mathrm{B}$ & U.S. & CYNC \\
\hline & 87 & NJC112 & Unknown & B & U.S. & CYNC \\
\hline & 88 & Redhaven & Halehaven x Kalhaven & $\mathrm{B}$ & U.S. & CYMC \\
\hline & 89 & Redtop & Sunhigh x July Elberta op. & $\mathrm{B}$ & U.S. & CYMF \\
\hline & 90 & Romance & Wilma $x$ Halehaven & B & U.S. & CYMF \\
\hline & 91 & Springtime & (Luken's honey x July Elberta) x Robin & $\mathrm{B}$ & U.S. & CWMC \\
\hline & 92 & Triumph & Alexander mutation & B & U.S. & CYMF \\
\hline \multirow[t]{3}{*}{ Korean cultivars } & 93 & Andongsumil & Unknown & $\mathrm{C}$ & Korea & CWMS \\
\hline & 94 & Janghowenhuangdo & Japanese yellow mutation & $\mathrm{C}$ & Korea & CYMC \\
\hline & 95 & Weolbongjosaeng & Kuragatawase mutation & $\mathrm{C}$ & Korea & CWNS \\
\hline Kindred species & 96 & Xinjiangdatianren & P.ferganensis & A & Xinjiang, China & CWMF \\
\hline
\end{tabular}

Data on parental relationships were obtained from Wang and Zhuang (2001).

y A = Beijing Forestry and Fruit Research Institute in China, B = Zhengzhou Fruit Tree Research Institute in China, C = Fruit Station of Sunchon National University in South Korea.

${ }^{x}$ First letter: $\mathrm{C}=$ common peach, $\mathrm{N}=$ nectarine, $\mathrm{F}=$ flat peach; second letter: $\mathrm{W}=$ white, $\mathrm{Y}=$ yellow; third letter: $\mathrm{N}=$ nonmelting flesh, $\mathrm{S}=$ semimelting flesh, $\mathrm{M}=$ melting flesh; fourth letter: $\mathrm{C}=$ clingstone, $\mathrm{S}=$ semi-clingstone, $\mathrm{F}=$ freestone. 
Table 2. The 33 SSR primer pairs used for genetic diversity study of 96 peach and nectarine cultivars with linkage group, number of polymorphic alleles, size range of PCR products, and polymorphic information content (PIC).

\begin{tabular}{|c|c|c|c|c|}
\hline SSRs & $\mathrm{LG}^{\mathrm{z}}$ & $\begin{array}{c}\text { Alleles } \\
\text { (no.) }\end{array}$ & $\begin{array}{l}\text { Size range } \\
\text { (bp) }\end{array}$ & PIC \\
\hline UDP 96-001 & G6(14) & 15 & $120-140$ & 0.94 \\
\hline UDP 96-005 & G1(33) & 12 & $140-170$ & 0.87 \\
\hline UDP 96-008 & G3(38) & 6 & $150-170$ & 0.70 \\
\hline UDP 96-013 & G2(27) & 7 & $180-210$ & 0.88 \\
\hline UDP 96-018 & $\mathrm{G} 1(0)$ & 10 & $220-260$ & 0.80 \\
\hline UDP 97-401 & G5(11) & 6 & $120-140$ & 0.73 \\
\hline UDP 98-406 & $\mathrm{G} 2(6)$ & 7 & $90-110$ & 0.84 \\
\hline UDP 98-409 & G8(41) & 11 & $130-160$ & 0.78 \\
\hline ВРPCТ 002 & G2(15) & 9 & $210-230$ & 0.67 \\
\hline ВРPCТ 005 & n.d..$^{y}$ & 2 & $130-140$ & 0.43 \\
\hline ВРРСТ 009 & G4(60) & 14 & $150-190$ & 0.98 \\
\hline ВРРСТ 013 & G2(20) & 4 & $170-190$ & 0.91 \\
\hline ВРPCТ 016 & G1(62) & 5 & $90-100$ & 0.87 \\
\hline ВРPCТ 017 & G5(21) & 12 & $160-190$ & 0.92 \\
\hline ВРРСТ 023 & G4(52) & 9 & $200-230$ & 0.82 \\
\hline ВРРСТ 025 & G6(52) & 5 & 190-200 & 0.92 \\
\hline ВРPCТ 026 & n.d. & 6 & $130-140$ & 0.76 \\
\hline ВРPCТ 031 & n.d. & 6 & $110-120$ & 0.77 \\
\hline ВРРСТ 034 & n.d. & 8 & $220-230$ & 0.82 \\
\hline ВРРСТ 038 & G5(33) & 12 & $120-140$ & 0.88 \\
\hline ВРРСТ 041 & n.d. & 3 & $210-220$ & 0.40 \\
\hline СРРСТ 002 & G3(32) & 5 & $80-100$ & 0.52 \\
\hline СРРСТ 003 & G1(36) & 13 & $140-170$ & 0.66 \\
\hline СРРСТ 005 & G4(11) & 7 & $150-170$ & 0.70 \\
\hline СРРСТ 006 & G8(17) & 5 & $180-210$ & 0.72 \\
\hline СРPCТ 013 & G5(30) & 13 & $150-160$ & 0.74 \\
\hline СРРСТ 019 & G1(69) & 9 & $170-190$ & 0.86 \\
\hline СРPCТ 026 & G1(38) & 11 & $170-200$ & 0.95 \\
\hline СРРСТ 031 & n.d. & 16 & $170-210$ & 0.92 \\
\hline Pchgms 1 & G2(34) & 3 & $190-200$ & 0.64 \\
\hline Pchgms 3 & G1(41) & 6 & $170-190$ & 0.76 \\
\hline Pchcms 1 & n.d. & 11 & $190-220$ & 0.92 \\
\hline Pchems 5 & G6(43) & 5 & $240-250$ & 0.62 \\
\hline Ps12A02 & n.d. & 10 & $170-210$ & 0.83 \\
\hline Mean & & 8.6 & & 0.80 \\
\hline
\end{tabular}

${ }^{2} \mathrm{LG}=$ linkage group, distance in centimorgans from the top of the linkage group as in the general Prunus map (Aranzana et al., 2003c). yn.d. = not determined

A dendrogram constructed from SSR data based on genetic distances of coefficient 1.50 classified the 96 cultivars into six groups: (Group I) northern Chinese and northwestern Chinese local cultivars; (Group II) southern Chinese local, Japanese, and North American cultivars; (Group III) P. ferganensis and 'Renmiantao'; (Group IV) Chinese dwarf cultivars; (Group V) 'Fenshouxing'; and (Group VI) 'Baishanbitao' (Fig. 1).

Group I contains mainly Chinese local cultivars originated from northern and northwestern areas with the exception of two Chinese local cultivars, 'Shilinhuangrou' and 'Yunshu 1', of the southern Chinese ecological type. Furthermore, this group can be divided into two subgroups at the coefficient level of 1.30. Subgroups I-1 and I-2 are the local white peach and local yellow peach, respectively, in the northern and northwestern areas in China. Particularly notable among them is 'Roupantao', a flat peach from Gansu province, with a 0.82 coefficient with 'Linbai
4', 'Linbai 7', 'Zhanghuang 7', and 'Linhuang 9', suggesting a close relation with Chinese local common fruit cultivars in the same area.

The southern Chinese local, Japanese, and North American cultivar group contains about $67 \%$ of all the cultivars evaluated and can be divided into four subgroups. Japanese white peach cultivars and Chinese flat peach cultivars, which all have white flesh, are in Subgroup II-1. 'Janghowenhuangdo', discovered from an introduction of Japanese yellow peach cultivars in South Korea, shows a close relation with 'Nishio Gold', a Japanese yellow peach, supporting its origin. Subgroup II-2 has mainly the NorthAmerican yellow cultivars, including two Japanese cultivars, 'Meisei' (yellow flesh) and 'Tasubanawase' (white flesh), and a Korean white cultivar, 'Weolbongjosaeng'. 'Shuguang', a cross of 'LeGrant' $x$ 'Ruiguang 2', is actually three-quarters North American-developed germplasm, so logically it should cluster with this group. Subgroup II-3 has only two Chinese cultivars, 'Jiangtao' and 'Xinbaitao', with a 0.72 coefficient. Most Chinese ornamental cultivars, 'Hongchuizhi', 'Hongyetao', 'Jiangtao', and 'Zhufenchuizhi', were clustered into Subgroup II-4. For the other ornamental peach cultivars, 'Honghuabitao' was assigned to Group I, 'Mantianhong' to Group II-1, and 'Baishanbitao' to Group VI.

Groups III, IV, and V are comprised of Chinese local ancient cultivars. Group III contains the ancient cultivars, 'Renmiantao' and 'Xinjiangdatianren'. The dwarf cultivar Shouxingtao and its hybrids with 'Hakuho' ('S9', 'S1', and 'S2') are included in Group IV with the otherdwarf cultivars, 'Shoufen' and 'Shoubai'. Another dwarf cultivar, 'Fenshouxing', is placed in Group V alone.

Group VI has only 'Baishanbitao', which is the most distant from other all cultivars with a 2.59 coefficient.

GENETIC RELATIONSHIPS AMONG GEOGRAPHICAL GROUPS. The genetic relationships and distances among all the groups are shown in Fig. 2 and Table 3. The peach cultivars studied in this experiment could be divided into two groups based on the similarity matrix. Northern Chinese and northwestern Chinese local cultivars were clustered together and differed from southern Chinese, Japanese white, Chinese flat, and the North American yellow groups (Fig. 2). Moreover, the local southern Chinese peach group had the closest (coefficient 0.439) genetic distance to the Japanese white peach group while the greatest distance was found between the North American cultivars and the northern Chinese and northwestern Chinese local cultivars (Table 3). The two botanical varieties, Chinese dwarf and ornamental cultivars, showed a great genetic distance from peaches and nectarines (ranging from 1.456 to 2.303). The greatest genetic distance was between the North American yellow peach group and Chinese dwarf peach (2.303), while the lowest was found between Chinese dwarf and southern Chinese local cultivars (1.456).

\section{Discussion}

GENETIC DIVERSITY AMONG ECOGEOGRAPHICAL TYPES OF $\boldsymbol{P}$. PERSICA. SSR markers are PCR-based and exhibit codominant inheritance. In Prunus L., these markers have been used widely for cultivar identification and genetic mapping (Aranzana et al., 2003c; Cipriani et al., 1999; Dirlewanger et al., 2002; Downey and Iezzoni, 2000; Testolin et al., 2000), and are a powerful genetic resource for phylogenetic studies (Aranzana et al., 2003b). Previous studies indicated that SSR markers are suitable for comparative genetic studies, and can facilitate the integration of genetic maps both within the Rosaceae and across wider taxo- 


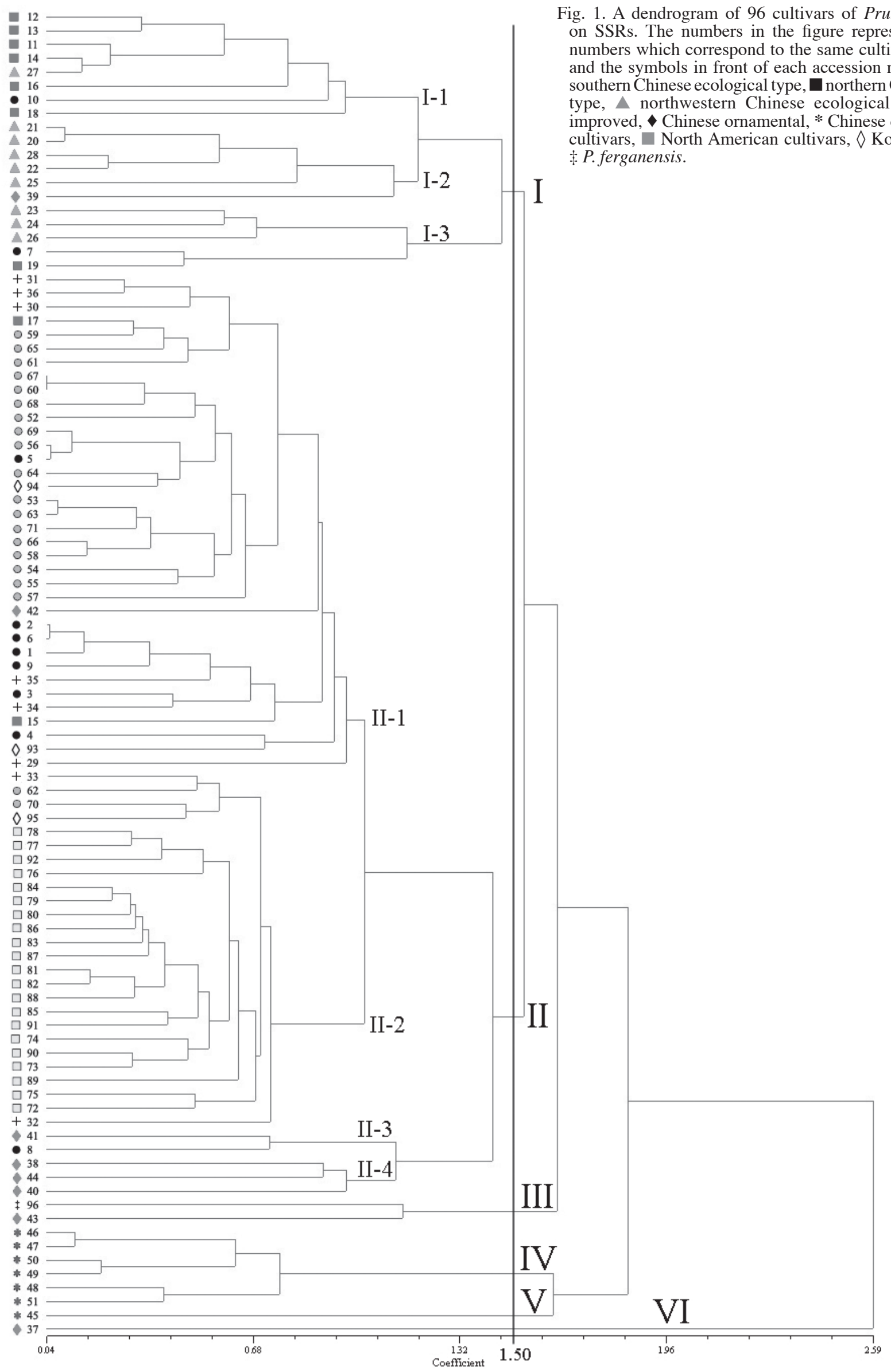




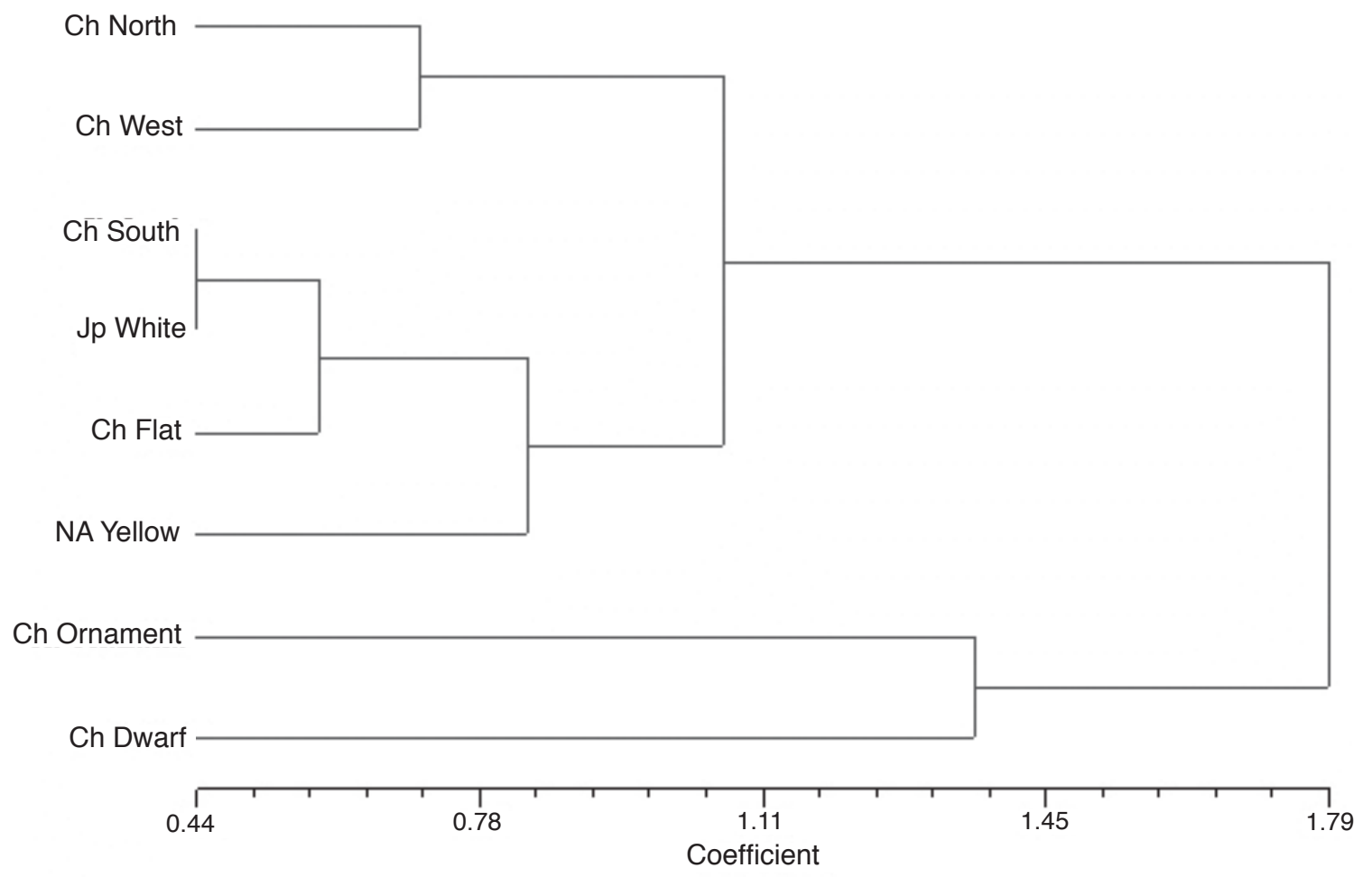

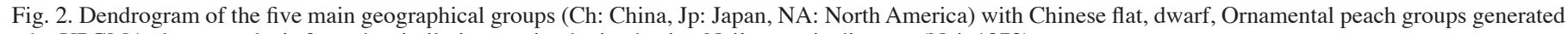
by UPGMA cluster analysis from the similarity matrix obtained using Nei's genetic distance (Nei, 1972).

Table 3. Similarity matrix of the five geographical groups with Chinese flat, dwarf, ornamental peach groups by using Nei's genetic distance (Nei, 1972).

\begin{tabular}{|c|c|c|c|c|c|c|c|}
\hline & $\begin{array}{l}\text { China, } \\
\text { north }\end{array}$ & $\begin{array}{c}\text { China, } \\
\text { northwest }\end{array}$ & $\begin{array}{l}\text { China, } \\
\text { south }\end{array}$ & $\begin{array}{l}\text { Japan, } \\
\text { white }\end{array}$ & $\begin{array}{c}\text { North America, } \\
\text { yellow }\end{array}$ & $\begin{array}{l}\text { China, } \\
\text { flat }\end{array}$ & $\begin{array}{c}\text { China, } \\
\text { ornamental }\end{array}$ \\
\hline China, northwest & 0.704 & 0.000 & & & & & \\
\hline China, south & 1.035 & 1.000 & 0.000 & & & & \\
\hline Japan, white & 0.848 & 1.017 & 0.439 & 0.000 & & & \\
\hline North America, yellow & 1.309 & 1.180 & 0.762 & 0.654 & 0.000 & & \\
\hline China, flat & 0.996 & 1.160 & 0.659 & 0.510 & 1.084 & 0.000 & \\
\hline China, ornamental & 1.989 & 1.691 & 1.515 & 1.714 & 1.925 & 1.535 & 0.000 \\
\hline China, dwarf & 1.917 & 1.830 & 1.456 & 1.893 & 2.303 & 1.696 & 1.368 \\
\hline
\end{tabular}

nomic boundaries.

The number of alleles and PIC values generated from each marker showed a large variation (Table 2). UDP96-001, UDP96-005, UDP96-018, ВРPCT009, ВРPCT017, ВРРCT038, CPPCT026, CPPCT031, pchcms1, and PS12A02 showed PIC values greater than 0.8 , and the number of generated alleles were more than 10. These results suggest that SSR markers would be very useful in the discernment of genetic relationships among cultivars as well as in genetic mapping.

The 33 primer pairs used in this study revealed very high polymorphism, with an average of 8.6 alleles per locus for the 96 peach and nectarine cultivars (Table 2 ). This average number of alleles per locus is much higher than the 2.2 to 4.5 obtained with a small quantity of cultivars (less than 50) by Ahmad et al. (2004), Sosinski et al. (2000), Testolin et al. (2000), and Yamamoto et al. (2003), and even higher than the 7.3 from 212 cultivars by Aranzana et al. (2003b). A higher number of alleles came from the larger set of cultivars (Aranzana et al., 2003b), but more importantly from a more diverse germplasm resource. China is the center of origin of peaches and nectarines. A high level of diversity should exist in the center of origin according to Vavilov (1930). The higher number of alleles obtained in this study resulted from the use of different botanical varieties, such as ornamental and dwarf peach cultivars and the local cultivars from different ecological types. The high diversity from the Chinese botanical varieties and local cultivars was confirmed in Fig. 1. Specifically, the northern Chinese and northwestern Chinese local types (Groups I, II-4, III, IV, and V) had much higher polymorphism than those from North America (Subgroup II-2) and Japan (Subgroup II-1).

EVOLUTIONARY RELATIONSHIPS AMONG BOTANICAL VARIETIES AND ECOgEographical Cultivars of $\boldsymbol{P}$. PERSiCA. Peaches and nectarines were grown at first in the northern plains of China, and then spread to southern China (Qu and Sun, 1990; Wang and Zhuang, 2001). Northern and northwestern Chinese local cultivars clustered together with a greater diversity than those from southern Chinese local cultivars (Fig. 2). This result indicates that the northern and northwestern Chinese local cultivars should be similar ecotypes, and southern Chinese local cultivars are a subset of the northern group and, perhaps, evolved from them. 
This result confirms the evolutionary status of cultivated peaches and nectarines based on the morphological traits and information from ancient Chinese books as mentioned above. However, some Chinese cultivars of the southern ecological type or originated from the northeastern Chinese type, such as 'Hongganlu', 'Xiangjiaotao', 'Chongbanyulu', and 'Huangjintao', belong to Subgroup II-1, indicating that the cultivars originating from northeastern China have a close phylogenetic relationship with the southern Chinese local cultivars.

Based on RAPD analysis, Yang et al. (2001) suggested that the northern and southern Chinese flat peach may have evolved in different ways, but both may have originated from the northern Chinese hard-flesh peach in China. The results obtained in this study based on SSR do not confirm the previous suggestion (Fig. 2). Judging from the fact that 'Roupantao', a flat peach originated from Gansu province, in Group I consisting of Chinese white and yellow cultivars, and 'Wuyuexianbiangan', a flat peach originating from Beijing, in Group II together with the other southern Chinese flat peaches (Subgroup II-1), the evolution of these two ancient cultivars, which originated in northern and northwestern area in China, is likely different. 'Roupantao' is similar to northern white cultivars, rather than other flat peach cultivars, while 'Wuyuexianbiangan' is closer to southern Chinese local cultivars at the molecular level. However, all Chinese flat peaches originating from southern areas of China clustered together with a smaller diversity compared with the northern and northwestern Chinese ecotypes, indicating its late evolutionary status.

The North American peach and nectarine cultivars originated, in general, from Chinese Cling from Shanghai, and western European and Japanese cultivars are mainly descendants of Chinese Cling and flat peaches from southern Chinese ecotypes, or are descendants of southern Chinese ecotypes with little North American and western European relationship (Qu and Sun, 1990). Group II in Fig. 2, accounting for $67 \%$ of the total cultivars, clearly classified Japanese white cultivars, southern Chinese local peach, and the North American yellow cultivars. This shows that Japanese cultivars and the North American yellow cultivars have a close phylogenetic relationship with southern Chinese local peaches.

'Janghowenhuangdo', known only as a mutant of a Japanese yellow cultivar, has a close genetic distance of 0.38 with Japanese yellow 'Nishio Gold', suggesting its possible origin. From the fact that another Korean improved cultivar, 'Andongsumil', has a close relationship with Japanese white cultivars as well as with Chinese 'Chongbanyulu', but less with the other southern Chinese and Korean cultivars, we suggest that these cultivars from different regions have a relationship to some degree with Japanese cultivars.

Chinese dwarf and ornamental cultivars are two types of botanical varieties of $P$. persica. The cultivation history of these two botanical varieties began much earlier than that for the melting peaches belonging to southern and northern Chinese ecological types, such as 'Shanghaishuimi' and 'Tianjinshuimi', based on ancient Chinese literature (Sheng, 1957). Cluster analysis using the similarity data between groups shows that Chinese dwarf and ornamental cultivars exhibited a great genetic distance to cultivated peaches and nectarines (Fig. 2), confirming their taxonomic placement as botanical varieties of $P$. persica. Moreover, Chinese dwarf peaches clustered with the other groups, perhaps signifying that dwarf cultivars are more ancient than ornamental ones or cultivated peaches and nectarines. 'Renmiantao', an ancient ornamental cultivar in China, separated with the main ornamental cultivars and was grouped independently with 'Xinjiangdatianren'. In addition, the other Chinese local ornamental cultivars were clustered in the same group as southern Chinese local, Japanese, and North American cultivars (Fig. 1). This indicates that 'Renmiantao' may be the most ancient ornamental cultivar among the cultivars selected for this study. Two other ornamental cultivars, 'Honghuabitao' and 'Mantianhong', were classified into the northern local cultivars group (Group I) and southern Chinese cultivars group (Group II), respectively. This can be explained by their origin. 'Honghuabitao' originated from Beijing, and thus it is closer to the northern Chinese peach cultivars. 'Mantianhong' is a hybrid of 'Hongshouxing' x 'Hakuho'. Although 'Mantianhong' was developed for ornamental use with wide adaptation, it still possesses a genetic background closer to Japanese cultivars due to its Japanese heritage ('Hakuho' is a Japanese cultivar).

TAXONOMIC PLACEMENT OF P. FERGANENSIS. Prunusferganensis is phenotypically different from common peach (Cheng et al., 2001) and was recorded as a species [Kov and Kost (see Wang, 1988); Yu, 1979)] or as a subspecies of P. persica ssp. ferganensis Kost et Riab. Based on the SSR analysis of this study, 'Xinjiangdatianren', a cultivar of P. ferganensis, is genetically closer to the old northern local ornamental cultivar Renmiantao. Yang et al. (2001), who studied the genetic relationships among peaches using RAPDs, indicated that 'Xinjiangdatianren' and another cultivar of $P$. ferganensis, 'Xinjiangxiaotianren', were both genetically closer to northern Chinese local cultivars. Cheng et al. (2001) obtained the same results as Yang et al. (2001). The data suggest that $P$. ferganensis is a botanical variety of $P$. persica or P. persica var. ferganensis.

Phylogenetic Relationship of 'Baishanbitao'. 'Baishanbitao', found and named in the late 1970s, is an outlying group of $P$. persica. Its morphological characteristics are intermediate between $P$. davidiana Carr. Franch. and $P$. persica. The fine shoots and smooth tree bark of 'Baishanbitao' cannot be differentiated from P. davidiana, and flowers of 'Baishanbitao' are similar to those of $P$. persica. Moreover, cytological study and scanning electron microscopy showed that meiosis of the megasporangium of 'Baishanbitao' was morphologically identical to that of $P$. davidiana, and the low germination rate of 'Baishanbitao' pollen may be because it is a distant hybrid, suggesting that 'Baishanbitao' is a P.davidiana-P.persica hybrid (Zhang et al., 1998). The results of SSR analysis in this study show that 'Baishanbitao' is different from P. persica, and this difference may be explained by this hypothesis.

\section{Literature Cited}

Ahmad, R., D. Potter, and S.M. Southwick. 2004. Genotyping of peach and nectarine cultivars with SSR and SRAP molecular markers. J. Amer. Soc. Hort. Sci. 129:204-210.

Anderson, JA., G.A. Churchill, J.E. Autirigue, and S.D. Tanksley. 1993. Optimizing parental selection for genetic linkage maps. Genome 36:181-186.

Aranzana, M.J., J. Garcia-Mas, J. Carbó, and P. Arús. 2002. Development and variability of microsatellite markers in peach. Plant Breeding 121:87-92.

Aranzana, M.J., P. Arús, and J. Carbo. 2003a. Using amplified fragment-length polymorphisms to identify peach cultivars. J. Amer. Soc. Hort. Sci. 128:672-677.

Aranzana, M.J., J. Carbó, and P. Arús. 2003b. Microsatellite variability in peach [Prunus persica (L.) Batsch]: Cultivar identification, marker mutation, pedigree inferences and population structure. Theor. Appl. Genet. 106:1341-1352. 
Aranzana, M.J., A. Pineda, P. Cosson, E. Dirlewanger, J. Ascasibar, G. Cipriani, C.D. Ryder, R. Testolin, A. Abbott, G.J. King, A.F. Iezzoni, and P. Arús. 2003c. A set of simple-sequence repeat (SSR) markers covering the Prunus genome. Theor. Appl. Genet. 106:819-825.

Belthoff, L.E., R. Ballard, A. Abbott, P. Morgens, A. Callahan, R. Scorza, W.V. Baird, and R. Monet. 1993. Development of a saturated linkage map of Prunus persica using molecular based marker systems. Acta Hort. 336:23-31.

Chaparro, J.X., D.J. Werner, D. O’Malley, and R.R. Sederoff. 1994. Targeted mapping and linkage analysis of morphological isozyme, and RAPD markers in peach. Theor. Appl. Genet. 87:805.

Cheng, Z.P., Z.W. Chen, C.G. Hu, X.X. Deng, and Z.R. Luo. 2001. Classification study of Xinjiang peach using RAPD markers. Acta Hort. Sinica 28:211-217.

Cipriani, G., G. Lot, W.G. Huang, M.T. MaHazzo, E. Peterlunger, and R. Testolin. 1999. AC/GT and AG/CT microsatellite repeats in peach [Prunus persica (L.) Batsch]: Isolation, characterization and crossspecies amplification in Prunus. Theor. Appl. Genet. 99:65-72.

Dib, C., S. Faure, C. Fizames, D. Samson, N. Drouot, A. Vignal, P. Millasseau, S. Marc, J. Hazan, E. Seboun, M. Lathrop, G. Gyapay, J. Mirissette, and J. Weissentach. 1996. Acomprehensive genetic mapof the human genome based on 5264 microsatellites. Nature 380:152-154.

Dietrich, W.F., J. Miller, R. Steen, M.A. Merchant, D. DamronBoles, Z. Husain, R. Dredge, M.H. Daly, K.A. Ingalls, T.J. O'Connor, C.A. Evans, M.M. DeAngelis, D.M. Levinson, L. Kruglyak, N. Goodman, N.G. Copelang, N.A. Jenkins, T.L. Hawkins, L. Stain, D.C. Page, and E.S. Lander. 1996. Acomprehensive genetic map of the mouse genome. Nature 380:350-360.

Dirlewanger, E., P. Cosson, M. Tavaud, M.J. Aranzana, C. Poizat, A. Zanetto, P. Arús, and F. Laigret. 2002. Development of microsatellite markers in peach [Prunus persica (L.) Batsch] and their use in genetic diversity analysis in peach and sweet cherry (Prunus avium L.). Theor. Appl. Genet. 105:127-138.

Downey, S.L. and A.F. Iezzoni. 2000. Polymorphic DNAmarkers in black cherry (Prunus serotina) are identified using sequences from sweet cherry, peach, and sour cherry. J. Amer. Soc. Hort. Sci. 125:76-80.

Doyle, J.J. and J.L. Doyle. 1990. Isolation of plant DNA from fresh tissue. Focus 12:13-15.

Gianfranceschi, L., N. Seglias, R. Tarchini, M. Komjanc, and C. Gessler. 1998. Simple sequence repeats for the genetic analysis of apple. Theor. Appl. Genet. 96:1069-1076.

Li, S.H., X.G. Xiao, and K.G. Jia. 1997. Cultivation of peaches and nectarines (in Chinese). Higher Education Press, Beijing, China.

Martinez-Gomez, P., S. Arulsekar, D. Potter, and T.M. Gradziel. 2003. Relationships among peach, almond, and related species as detected by simple sequence repeat markers. J. Amer. Soc. Hort. Sci. 128:667-671.

Nei, M. 1972. Genetic distance between populations. Amer. Naturalist 106:283-292.

Qu, Z.Z. and Y.W. Sun. 1990. Species in fruit trees (in Chinese). Agricultural Press, Beijing, China.

Rajapakes, S., L.E. Belthoff, G. He, A.E. Estager, R. Scorza, I. Verde, R.E. Ballard, W.V. Baird, A. Callahan, R. Monet, and A.G. Abbott. 1995. Genetic linkage mapping in peach using morphological, RFLP and RAPD markers. Theor. Appl. Genet. 90:503-510.

Rohlf, F.J. 1994. NTSYS-pc version 2.1. Exeter software. Setauket, N.Y.

Sheng, C.G. 1957. The cultivation history of peaches in China. J. Nanjing Agr. Univ. 2:103-105.

Sosinski, B., M. Gannavarapu, L.D. Hager, L.E. Beck, G.J. King, C.D. Ryder, S. Rajapakse, W.V. Baird, R.E. Ballard, and A.G. Abbott. 2000. Characterization of microsatellite markers in peach [Prunus persica (L.) Batsch]. Theor. Appl. Genet. 101:421-428.

Testolin, R., T. Marrazzo, G. Cipriani, R. Quarta, I. Verde, M.T. Dettori, M. Pancaldi, and S. Sansavini. 2000. Microsatellite DNA in peach [Prunus persica (L.) Batsch.] and its use in fingerprinting and testing the genetic origin of cultivars. Genome 43:512-520.

Vavilov, N.I. 1930. Wild progenitors of the fruit trees of Turkistan and the Caucasus and the problem of the origin of fruit trees. Proc. 9th Intl. Hort. Congr., Royal Hort. Soc., London. p. 271-286.

Wang, Y., L.L. Georgi, T.L. Zhebentyayeva, G.L. Reighard, R. Scorze, and A.G. Abbott. 2002. High-throughput targeted SSR marker development in peach (Prunus persica). Genome 45:319-328.

Wang, Y.L. 1988. Species of deciduous fruit trees (in Chinese). China Agricultural Press, Beijing, China.

Wang, Z.H. and E.J. Zhuang. 2001. Chinese monograph of fruit trees (in Chinese). China Forestry Press, Beijing, China.

Yamamoto, T., K. Mochida, T. Imai, Y.Z. Shi, I. Ogiwara, and T. Hayashi. 2002. Microsatellite markers in peach [Prunus persica (L.) Batsch] derived from and enriched genomic and cDNA libraries. Mol. Ecol. Notes 2:298-301.

Yamamoto, T., K. Mochida, T. Imai, T. Haji, H. Yaegaki, M. Yamaguchi, N. Matsuta, I. Ogiwara, and T. Hayashi. 2003. Parentage analysis in Japanese peaches using SSR markers. Breeding Sci. 53:35-40.

Yang, X.G., K.C. Zhang, L. Qin, and Y.X. Wang. 2001. RAPD analysis of germplasm resources on peach. J. Fruit Sci. 18:276-279.

Yu, D.J. 1979. Taxonomy of Chinese fruit trees (in Chinese). China Agricultural Press, Beijing, China.

Zhang, X.Y., H.P. Chen, and W.K. Wang. 1998. The origin of Prunus persica cv. Baihua Shanbi Tao. J. Beijing For. Univ. 20:51-55. 